\section{Prof. Alberto Carlos Riccardi}

\section{IUGS Councilor}

Alberto C. Riccardi is Professor and Head of the Invertebrate Palaeontology Division at the National University of La Plata and Superior Researcher of the Argentina National Research Council.

He was born on June 18, 1942 in Buenos Aires, Argentina, and studied Geology at the National University of La Plata, earning his Doctor in Natural Sciences in 1968. His thesis was on the stratigraphy of a key area of the southern Patagonian Cordillera, with the main emphasis on Cretaceous biostratigraphy. From 1963 to 1968, he was assistant geologist and palaeontologist for the Argentina Geological Survey, working on Mesozoic invertebrates and stratigraphy.

In 1965, he began to work on Middle Jurassic ammonites and biostratigraphy of west central Argentina. Ammonites collected at that time and in the following years were taken for palaeontological study to McMaster University, Canada, in 1968, where Prof. Riccardi was a postdoctoral fellow with the National Research Councils of Argentina and Canada. There was born, with the co-authorship of Professor G.E.G. Westermann, a monographic series on the Middle Jurassic of the Andes that would continue for the decades.

He returned to Argentina in 1970 and became Assistant Professor at the National University of La Plata and researcher for the Argentina National Research Council. In 1974, the J.S. Guggenheim Memorial Foundation awarded him a fellowship so that he could continue his studies on Mesozoic stratigraphy in Canada, where he stayed for the next two years. At the end of the sixties and throughout the seventies he extended his research interest in the Mesozoic to other areas of the Americas, including Mexico and Peru.

He was invited to the reconstitutional meeting of the International Subcommission on Jurassic Stratigraphy in 1977, of which he became a voting member. In 1979, he was elected as an individual member of the International Subcommission on Stratigraphic Classification and participated in the elaboration of the second edition of the International Stratigraphic Guide.

At the end of the seventies he was elected President of the Argentina Palaeontological Society and was offered a position as Palaeontologist with the Geological Survey of Canada, in Ottawa. His work on Upper Cretaceous ammonoids and biostratigraphy, mainly from the Western Interior of Canada, resulted in several reports and papers, including a monograph on ammonoids of the Upper Cretaceous Bearpaw Formation.

In 1981 Prof. Riccardi returned to the National University of La Plata, where in 1986 he became full Professor and Head of the Invertebrate Palaeontology Division of the La Plata Museum and Head of the Department of Palaeontology. Since then, he has taught several courses on Palaeontology and Stratigraphy, and has supervised a number of $\mathrm{PhD}$ thesis and researchers (La Plata and Buenos Aires Universities). During those years, he was appointed Chairman of the Argentina Committee on Stratigraphy and of the Argentina Subcommission on Jurassic Stratigraphy. Under his leadership, the second edition of the Argentinean Code on Stratigraphical Nomenclature was edited. The preparation of the Stratigraphic Lexicon of Argentina also began, with its first volume devoted to the Jurassic, of which he was the main editor.

In 1989, he was appointed Visiting Professor in the Department of Geology of McMaster University, Canada, where he finished two new monographs of the series on Middle Jurassic ammonites of the Andes.

From 1991 until 1995, he was Chairman of Advisory Committees on Earth Sciences for the Argentina National Research Council and since 1993 member of the National Committee on Geological Mapping for the Argentina Geological Survey. He was Chief Editor of the journals of the Argentina Palaeontological and Geological Societies.
Beginning in 1991 and for four periods until 1999, he was elected President of the Argentina Geological Society and of the Argentina National Committee of the IUGS. He devoted much of his time to improve the quality and visibility of the quarterly journal published by the society. Through his efforts, the Argentina Geological Society signed an official agreement with the Cuban Geological Society and became an Allied Society to the Geological Society of America and Affiliated Society to the American Association of Petroleum Geologists. He was Argentina's National Delegate to the International Geological Congresses of Kyoto (1992), Beijing (1996) and Rio de Janeiro (2000). He was Chairman of the Organising Committee of the 4th International Congress on Jurassic Stratigraphy (Mendoza, 1994), and (for three periods, since 1991) Vice President of the International Palaeontological Association, and Vice Chairman (1992-1994) and Chairman (for two and half periods, since 1994) of the International Subcommission on Stratigraphic Classification (ISSC). During those years the ISSC published an abridged version of the International Stratigraphic Guide, and organised working groups to review sequence stratigraphy and cyclostratigraphy. Prof. Riccardi was an active member of several IGCP Projects, especially IGCP Project 171 "Circum-Pacific Jurassic" and was Co-Leader of IGCP Project 322 "Correlation of Jurassic Events in South America". In 2000, he was elected Councillor (2002-2006) of the Executive Committee of the International Union of Geological Sciences.

Riccardi's research has focused on bio- and chronostratigraphy of the Jurassic of west central Argentina and of the Cretaceous of southern Patagonia, leading a team of geologists and palaeontologists working on different fields. As a result, new information has been obtained for the Mesozoic of west-central Argentina, especially that related to the marine Triassic, Bathonian, and Middle Jurassic in general. Under his leadership a multiple-controlled stratigraphy has been established for the Andean Jurassic, using ammonites, bivalves, brachiopods and calcareous microfossils, with the subsequent addition of data on paleomagnetic reversals and stable isotopes. As for the Mesozoic of southern Patagonia, a zonal scheme based on ammonites has been proposed and used, to demonstrate that all stages of the Cretaceous are represented, and to establish the correct ages and relationships of several lithostratigraphic units. He has also published a general synthesis on the geology of the Jurassic and Cretaceous of southern South America and has devoted time to study the history of geology, especially in relation to geologists and palaeontologists who have worked on Patagonia and on the Mesozoic of South America.

Prof. Riccardi is the author of more than 100 scientific papers, monographs and books, mostly on Jurassic and Cretaceous stratigraphy and ammonoid palaeontology, 50 unpublished technical reports, and 60 technical and popular publications, and short notes on different geological topics.

He has received the following awards: B. Houssay (1987, Argentina National Research Council), Chemical, Medical and Natural Sciences (1990, Buenos Aires Province Government), E.L. Holmberg (1991, Argentina National Academy of Exact, Physical and Natural Sciences), National Prize in Geosciences - Geology, Geophysics, Oceanography and Meteorology - (1992, Government of Argentina), Konex of Platin in Earth Sciences - Geology, Geophysics and Oceanography - (1993, Konex Foundation), Argentina Geological Society (1996), Palaeontological Merit (1997-1999, Argentina Palaeontological Society). He is an Honorary Member of the Argentina Palaeontological Society (1995), a Member of the Argentina National Academy of Sciences (1995), and an Honorary Fellow of the Geological Society of America (2001).

\section{Address:}

Prof. Alberto C. Riccardi

Facultad de Ciencias Naturales y Museo,

Universidad Nacional de la Plata,

Paseo del Bosque s/n, 1900 la Plata,

ARGENTINA

Tel: +54 2214257744 ;

ax: +54 2214257527

E-mail: riccardi@museo.fcnym.unlp.edu.ar 